\title{
Respon Pemberian Beberapa Konsentrasi BAP dan IAA terhadap Pertumbuhan Sub-Kultur Anggrek Cymbidium (Cymbidium finlaysonianum Lindl.) secara In-Vitro
}

\author{
Eva Yulia ${ }^{1 *}$, Nurisna Baiti ${ }^{2}$, Rd Selvy Handayani ${ }^{2}$ dan Nilahayati $^{2 *}$ \\ ${ }^{1}$ Mahasiswa Program Magister Agroekoteknologi Fakultas Pertanian Universitas Malikussaleh, Aceh Utara \\ ${ }^{2}$ Program Studi Agroekoteknologi Fakultas Pertanian Universitas Malikussaleh, Aceh Utara \\ *Corresponding Author: nilahayati@ unimal.ac.id
}

\begin{abstract}
ABSTRAK
Cymbidium termasuk kedalam salah satu jenis anggrek yang sangat digemari oleh masyarakat. Hal ini disebabkan karena cymbidium memiliki bentuk dan warna bunga yang bervariasi dan jumlah kuntum per tangkai yang banyak. Selain itu, anggrek ini juga memiliki harga jual yang tinggi sehingga dapat dijadikan sebagai peluang usaha sangat menjanjikan. Perbanyakan tanaman anggrek menggunakan biji sangat sulit dilakukan karena biji anggrek tidak mempunyai endosperm sehingga pada kondisi normal tidak dapat berkecambah. Oleh karena itu, biji anggrek cymbidium hasil silangan yang unik perlu dilakukan perbanyakan tanaman secara modern dengan kultur jaringan. Tujuan dari penelitian adalah untuk mengetahui pengaruh pemberian beberapa konsentrasi BAP dan IAA terhadap pertumbuhan sub kultur anggrek Cymbidium secara in vitro. Penelitian dilakukan di Laboratorium Kultur Jaringan Tanaman Fakultas Pertanian Universitas Malikussaleh Kabupaten Aceh Utara pada bulan Maret-Mei 2020. Rancangan penelitian yang digunakan adalah rancangan acak lengkap faktorial. Faktor pertama adalah konsentrasi BAP $(0 \mathrm{mg} / \mathrm{L}, 1 \mathrm{mg} / \mathrm{L}$, dan $2 \mathrm{mg} / \mathrm{L})$. Faktor kedua adalah konsentrasi IAA $(0 \mathrm{mg} / \mathrm{L}, 0,5 \mathrm{mg} / \mathrm{L}$, dan $1 \mathrm{mg} / \mathrm{L}$ ). Percobaan diulang sebanyak $10 \mathrm{kali}$, sehingga secara keseluruhan diperoleh 90 unit percobaan. Pengamatan dilakukan terhadap peubah waktu tumbuh tunas, waktu tumbuh akar, jumlah tunas, jumlah akar, persentase kontaminasi, jumlah daun dan tinggi tunas. Hasil penelitian menunjukkan bahwa perlakuan BAP berpengaruh terhadap waktu tumbuh tunas, jumlah tunas, jumlah akar pada umur 2 MSTdan jumlah daun. Perlakuan terbaik terdapat pada perlakuan BAP $1 \mathrm{mg} / \mathrm{L}$. Perlakuan IAA berpengaruh terhadap jumlah tunas pada umur 4 MST. Perlakuan terbaik terdapat pada perlakuan IAA 0 $\mathrm{mg} / \mathrm{L}$. Terjadi interaksi antara pemberian BAP dan IAA pada sub kultur anggrek Cymbidium terhadap peubah jumlah tunas. Interaksi terbaik terdapat pada perlakuan B1I0 (BAP $1 \mathrm{mg} / \mathrm{L}+\mathrm{IAA} 0 \mathrm{mg} / \mathrm{L}$ ).
\end{abstract}

Kata kunci: anggrek Cymbidium, in-vitro, IAA, BAP

\begin{abstract}
One type of orchid that is very popular in Indonesia is cymbidium. Cymbidium has a lot of flowers and high economic value, so it can be used as a business opportunity. Propagation of orchid seeds is very difficult because orchid seeds do not have an endosperm. It needs modern propagation methods, namely in vitro propagation. The success of tissue culture is strongly influenced by the use of growth regulators with the appropriate concentrations. The purpose of this study was to determine the effect of BAP and IAA on sub culture of Cymbidium orchids in vitro. The research was conducted at the Plant Tissue Culture Laboratory, Faculty of Agriculture, University of Malikussaleh, North Aceh from March-May 2020. This researches used complete randomized design with two factors. The first factor is the level of BAP concentration: $0 \mathrm{mg} / \mathrm{L}(\mathrm{B} 0), 1 \mathrm{mg} / \mathrm{L}$ (B1), and $2 \mathrm{mg} / \mathrm{L}$ (B2). The second factor is the level of IAA concentration: $0 \mathrm{mg} / \mathrm{L}$ (I0), $0.5 \mathrm{mg} / \mathrm{L}$ (I1), and $1 \mathrm{mg} / \mathrm{L}$ (I2). There were 9 combination of treatment with 10 replications so that 90 experimental units were obtained. The results showed that BAP had an effect on the time of shoot growth, number of shoots, number of roots (2 WAP) and number of leaves (6 and 8 WAP). The best treatment is at the BI $(1 \mathrm{mg} / \mathrm{L})$ treatment. IAA had an effect on the number of shoots at 4 WAP. The best treatment is at the $\mathrm{I} 0(0 \mathrm{mg} / \mathrm{L})$ treatment. the results showed that an interaction between BAP and IAA administration in the Cymbidium orchid sub culture on the variable amount of shoots. The best interaction is in the treatment B1I0 (BAP $1 \mathrm{mg} / \mathrm{L}+$ IAA $0 \mathrm{mg} / \mathrm{L}$ ).
\end{abstract}

Keywords: Cymbidium orchid, in-vitro, IAA, BAP 


\section{PENDAHULUAN}

Tanaman anggrek termasuk ke dalam salah satu jenis tanaman hias yang sangat digemari oleh masyarakat di Indonesia. Tanaman anggrek memiliki nilai estetika yang tinggi, disebabkan karena tanaman ini mempunyai warna bunga yang bervariasi disertai bentuk dan ukuran bunga yang beraneka ragam (Widiastoety, 2010). Salah satu jenis anggrek yang sangat disukai oleh masyarakat adalah anggrek dari genus Cymbidium. Anggrek Cymbidium merupakan salah satu jenis anggrek epifit dengan sifat pertumbuhan batang simpodial (tidak memiliki batang utama) (Amalia et al., 2015). Anggrek Cymbidium memiliki jumlah kuntum bunga yang lebih banyak dengan bentuk dan warna bunga yang sangat bagus. Selain itu anggrek Cymbidium juga memiliki harga jual yang tinggi sehingga dapat dijadikan sebagai peluang bisnis yang sangat menjanjikan.

Persilangan tanaman anggrek menghasilkan buah yang mengandung jutaan biji di dalamnya. Perbanyakan anggrek dengan mengunakan biji sangat sulit dilakukan, karena biji tanaman anggrek tidak memiliki endosperm sehingga tidak dapat berkecambah pada kondisi normal. Oleh karena itu, untuk kelangsungan hidup tanaman ini diperlukan perbanyakan tanaman secara modern yaitu dengan perbanyakan in vitro. Perbanyakan in vitro atau kultur jaringan adalah suatu metode mengisolasi bagian tanaman dan menumbuhkannya secara aseptis sehingga bagian tanaman tersebut dapat memperbanyak diri dan beregenerasi menjadi tanaman yang lengkap kembali. Salah satu tahapan dalam kultur jaringan yaitu sub kultur.

Sub kultur merupakan proses penanaman kembali tanaman atau calon tanaman hasil kultur jaringan pada media yang baru. Elfiani \& Jakoni (2015) menyatakan bahwa sub kultur adalah usaha untuk menggantikan media kultur jaringan dengan media yang baru, sehingga terpenuhinya kebutuhan nutrisi untuk pertumbuhan tanaman. Sub kultur pada umumnya bertujuan untuk memperbanyak jumlah tanaman dan mencegah hilangnya nutrisi untuk pertumbuhan tanaman. Sub kultur dilakukan apabila tanaman sudah tumbuh memenuhi botol, atau tanaman sudah berada terlalu lama di dalam botol, sehingga pertumbuhannya sudah mulai berkurang akibat kekurangan unsur hara. Bahan tanaman yang digunakan untuk dilakukan sub kultur bersumber dari tanaman steril, sehingga kemungkinan terjadinya kontaminasi rendah.

Zat pengatur tumbuh merupakan (ZPT) salah satu faktor yang mempengaruhi keberhasilan perbanyakan tanaman dengan metode kultur jaringan (Raharjo et al., 2012). ZPT adalah senyawa organik yang dapat meningkatkan, menghambat bahkan dapat merubah proses fisiologi tanaman. Jenis zat pengatur tumbuh yang sering digunakan dalam metode kultur jaringan yaitu golongan sitokinin dan auksin. Sitokinin berperan dalam mempercepat pembelahan sel, perkembangan daun dan tunas adventif serta diferensiasi tunas. Auksin berperan dalam mempengaruhi pemanjangan sel, diferensiasi jaringan dan menginisiasi pembentukan akar. Zat pengatur tumbuh sitokinin dapat bersumber dari sitokinin sintetik yaitu Benzyl Amino Purine (BAP), sedangkan untuk auksin dapat menggunakan auksin sintetik misalnya Indole Acetic Acid (IAA) (Mukarlina et al., 2017).

BAP berfungsi sebagai perangsang pertumbuhan tunas, berpengaruh terhadap metabolisme sel, dan berfungsi sebagai pendorong proses fisiologis yang bergantung pada konsentrasi yang digunakan (Mashud, 2013). Pemberian BAP dengan konsentrasi tinggi tidak memberikan pengaruh yang baik, bahkan dapat menghambat pertumbuhan dan perkembangan tanaman (Suhita, 2008).

Pemberian BAP dengan konsentrasi 0 - 2 ppm pada tanaman anggrek larat (Dendrobium phalaenopsis Fitzg) menghasilkan kenaikan jumlah tunas, namun jumlah tunas akan menurun pada konsentrasi BAP 3 ppm (Mahadi, 2016). Hasil penelitian Hartati et al. (2014) pada organogenesis hasil persilangan Dendrobium merbelianum dengan Dendrobium liniale dengan pemberian BAP 2 ppm menghasilkan jumlah daun dan panjang daun tertinggi. Purita et al. (2017) menyatakan bahwa penggunaan media MS dengan penambahan BAP dengan konsentrasi 2 ppm menghasilkan waktu tumbuh daun yang baik pada subkultur jaringan tanaman nanas (Ananas comosus L. Merr).

IAA berfungsi sebagai perangsang pembelahan dan pembesaran sel serta perangsang aktivitas sel di dalam jaringan tanaman (Yuniati, 2018). Jika konsentrasi IAA yang diberikan terlalu tinggi maka akan dapat menghambat proses pembelahan sel, bahkan dapat membuat tanaman mati akibat dapat mensintesis ZPT lainnya seperti etilen yang fungsinya dapat bertolak belakang dengan auksin (Wahidah \& Hasrul, 2017).

Mahadi (2016) menyatakan bahwa pemberian IAA pada anggrek larat (Dendrobium phalaenopsis Fitzg) konsentrasi 0,5 ppm berpengaruh nyata terhadap waktu tumbuh tunas. Hasil penelitian Wahidah \& Hasrul (2017) menyatakan bahwa pemberian IAA dengan 
konsentrasi $1 \mathrm{ppm}$ mempercepat pembentukan mata tunas pisang sayang (Musa paradisiaca $\mathrm{L}$. Var. Sayang). Menurut Jihadiyah (2018) pemberian IAA $0,5 \mathrm{ppm}$ menghasilkan jumlah akar paling banyak pada tanaman tin (Ficus carica L.).

Berdasarkan permasalahan di atas maka dilakukan penelitian yang bertujuan untuk mengetahui pengaruh pemberian zat pengatur tumbuh IAA dan BAP terhadap pertumbuhan sub kultur anggrek Cymbidium secara in vitro.

\section{METODE PENELITIAN}

Pelaksanaan penelitian ini dilakukan di Laboratorium Kultur Jaringan Tanaman Fakultas Pertanian Universitas Malikussaleh Kabupaten Aceh Utara. Waktu penelitian dimulai dari bulan Maret sampai Mei 2020.

Penelitian ini menggunakan Rancangan Acak Lengkap (RAL) faktorial. Faktor pertama konsentrasi zat pengatur tumbuh BAP, terdiri dari 3 taraf yaitu B0 (0 mg/L), B1 (1mg/L), dan B2 $(2 \mathrm{mg} / \mathrm{L})$. Faktor kedua konsentrasi IAA, terdiri dari 3 taraf yaitu I0 $(0 \mathrm{mg} / \mathrm{L})$, I1 $(0,5 \mathrm{mg} / \mathrm{L})$, dan I2 $(1 \mathrm{mg} / \mathrm{L})$. Oleh karena itu diperoleh 9 kombinasi perlakuan dengan ulangan sebanyak 10 kali, sehingga diperoleh 90 unit percobaan.

Persiapan sterilisasi yang dilakukan dalam pelaksanaaan penelitian ini meliputi sterilisasi alat (botol kultur, scalpel, cawan petri, kertas buram, dan pinset), dan sterilisasi ruang tanam. Alat-alat yang digunakan dicuci dengan menggunakan larutan cuci piring kemudian dikeringkan. Botol kultur yang sudah bersih dan kering disterilisasi menggunakan oven selama 2 jam dengan suhu $170^{\circ} \mathrm{C}$, sedangkan alat tanam (scalpel, cawan petri, kertas buram, dan pinset) dibungkus dengan menggunakan kertas dan plastik bening, kemudian disterilisasi menggunakan autoclave selama 30 menit dengan suhu $121^{\circ} \mathrm{C}$. Alat-alat yang sudah steril diletakkan di dalam ruang inkubasi dengan suhu $24-26^{\circ} \mathrm{C}$. Sterilisasi ruang tanam yang digunakan pada saat penanaman dapat dilakukan dengan cara penyinaran lampu UV pada LAFC (Laminar Air Flow Cabinet) selama 30 menit sebelum penanaman, kemudian LAFC disemprot dengan alkohol $70 \%$.

Media yang digunakan adalah media dasar MS, yang terdiri dari hara makro dan hara mikro.Sebelum membuat media tanam MS terlebih dahulu membuat larutan stok.Larutan stok berfungsi untuk mencegah penimbangan bahan kimia yang berulang-ulang, dan sebagai simpanan untuk membuat media apabila media yang dibutuhkan tidak cukup. Selanjutnya dilakukan pembuatan media MS, media MS +
BAP, media MS + IAA dan media MS+ BAP dan IAA.

Pengamatan dilakukan mulai hari pertama setelah penanaman sampai delapan minggu setelah tanam. Peubah-peubah yang diamati adalah waktu tumbuh tunas, waktu tumbuh akar, persentase kontaminasi, jumlah tunas, jumlah daun, jumlah akar dan tinggi tunas. Data dianalisis dengan analisis ragam uji $\mathrm{F}$ pada taraf $5 \%$.

\section{HASIL DAN PEMBAHASAN}

\section{Waktu Tumbuh Tunas dan Akar}

Hasil uji $F$ menunjukkan bahwa tidak terdapat interaksi antara perlakuan BAP dan IAA terhadap waktu tumbuh tunas dan waktu tumbuh akar tanaman anggrek Cymbidium. Hasil uji lanjut terhadap rata-rata peubah waktu tumbuh tunas dan waktu tumbuh akar akibat perlakuan konsentrasi BAP dan IAA disajikan pada Tabel 1.

Tabel 1 memperlihatkan bahwa perlakuan BAP secara tunggal berpengaruh terhadap peubah waktu tumbuh tunas. Perlakuan BAP dengan konsentrasi $1 \mathrm{mg} / \mathrm{L}$ dapat menginduksi munculnya tunas Cymbidium lebih cepat yaitu 13,91 HST, sedangkan tanpa pemberian BAP ( BAP $0 \mathrm{mg} / \mathrm{L}$ ) menginduksi tunas lebih lama yaitu 19,69 HST. Perlakuan IAA secara statistik tidak berpengaruh terhadap peubah waktu tumbuh tunas. Namun secara rataan, perlakuan tanpa pemberian IAA $(0$ $\mathrm{mg} / \mathrm{L}$ ) dapat menginduksi munculnya tunas dalam waktu yang lebih cepat yaitu 15,02 HST.

Keberhasilan dalam kultur jaringan ditandai dengan munculnya tunas pada eksplan. Kecepatan munculnya tunas ditentukan oleh kondisi eksplan dan penggunaan zat pengatur tumbuh dengan konsentrasi yang sesuai. Sitokinin adalah zat pengatur tumbuh yang dapat memacu pembelahan dan perkembangan sel, mendorong proses morfogenesis serta membantu pembentukan kloroplas. BAP merupakan salah satu jenis sitokinin yang dapat membantu pembentukan tunas dan menstimulasi pembelahan sel pada bagian tanaman. Pemberian BAP dengan konsentrasi 1 dan $2 \mathrm{mg} / \mathrm{L}$ dapat menginduksi tunas lebih cepat dibandingkan tanpa pemberian BAP. Hal ini sesuai dengan pernyataan Mufa'adi (2004) bahwa induksi tunas dan multiplikasi tunas akan lebih cepat terjadi dengan penambahan zat pengatur tumbuh sitokinin. Sitokinin berpengaruh untuk aktifitas pembelahan sel, dengan adanya penambahan sitokinin proses pembelahan sel akan berlangsung cepat, sehingga tunas yang terbentuk juga akan lebih cepat.

Perlakuan IAA tidak berpengaruh terhadap peubah waktu tumbuh tunas tanaman anggrek 
Cymbidium. Hal ini terjadi karena IAA merupakan hormon auksin yang lebih berperan dalam pembentukan akar. George dan Sherrington (1984) menyatakan bahwa proses terbentuknya akar dan tunas sangat dipengaruhi oleh konsentrasi sitokinin dan auksin yang ditambahkan ke dalam media serta interaksi antara sitokinin atau auksin endogen yang terdapat di dalam eksplan itu sendiri. Auksin endogen di dalam eksplan kemungkinan sudah mencukupi kebutuhan proses pembentukan tunas.

Tabel 1 memperlihatkan bahwa perlakuan BAP secara statistik tidak berpengaruh terhadap waktu tumbuh akar. Konsentrasi BAP $1 \mathrm{mg} / \mathrm{L}$ memiliki nilai rataan tercepat dalam pembentukan akar. Perlakuan IAA secara statistik tidak berpengaruh terhadap waktu tumbuh akar. Konsentrasi IAA $1 \mathrm{mg} / \mathrm{L}$ memiliki nilai rataan tercepat dalam pembentukan akar.

Waktu tumbuh akar sangat berperan dan mempengaruhi pertumbuhan dan perkembangan tanaman, karena melalui akar tanaman bisa menyerap nutrisi untuk pertumbuhannya. Hasil pengamatan menunjukkan bahwa perlakuan BAP tidak berpengaruh terhadap waktu tumbuh akar. Hal ini sesuai dengan pernyatan Alitalia (2008) bahwa pemberian BAP tidak berpengaruh terhadap waktu tumbuh akar tanaman Nepenthes mirabilis. BAP merupakan hormon sitokinin yang lebih berperan dalam pembentukan tunas, penggunaan BAP tidak efektif untuk pembentukan akar. Penggunaan BAP yang terlalu tinggi dapat menghambat inisiasi akar dan pertumbuhan akar. Maninggolang et al. (2018) menyatakan bahwa penggunaan BAP $3 \mathrm{mg} / \mathrm{L}$ menunjukkan jumlah akar yang rendah pada tanaman brokoli (Brassica oleracea L. var. Italica Plenck).

Pada kultur jaringan pembentukan akar dapat didorong dengan penambahan hormon auksin ke dalam media. Hasil pengamatan menunjukkan bahwa Perlakuan IAA tidak berpengaruh terhadap waktu tumbuh akar. Sulasiah et al. (2015) menyatakan bahwa pemberian IAA berpengaruh terhadap waktu tumbuh akar Dendrobium sp. Akan tetapi penelitian ini tidak sesuai dengan pernyataan tersebut, hal ini dapat disebabkan karena penggunaan konsentrasi IAA yang diberikan mungkin terlalu tinggi atau terlalu rendah.

\section{Jumlah Tunas}

Hasil analisis ragam menunjukkan bahwa terdapat interaksi antara perlakuan BAP dan IAA terhadap jumlah tunas. Data uji lanjut interaksi konsentrasi BAP dan IAA terhadap jumlah tunas disajikan pada Tabel 2.

Berdasarkan Tabel 2 dapat dilihat bahwa kombinasi perlakuan BAP dan IAA berpengaruh terhadap peubah jumlah tunas pada umur 4 MST, jumlah tunas terbanyak terdapat pada kombinasi perlakuan B1I0 (BAP $1 \mathrm{mg} / \mathrm{L}$ + IAA $0 \mathrm{mg} / \mathrm{L}$ ) yaitu dengan rerata 4,12 tunas. Jumlah tunas terendah terdapat pada kombinasi perlakuan B0I1 (BAP 0 $\mathrm{mg} / \mathrm{L}+$ IAA $0,5 \mathrm{mg} / \mathrm{L}$ ) yaitu dengan rerata 1,00 tunas. Data uji lanjut pengaruh perlakuan BAP dan IAA secara tunggal disajikan pada Tabel 2.

Tabel 3 dengan jelas memperlihatkan bahwa perlakuan BAP secara tunggal berpengaruh terhadap peubah jumlah tunas tanaman anggrek Cymbidium pada umur 2 MST, 6 MST dan 8 MST. Jumlah tunas paling banyak terdapat pada perlakuan BAP dengan konsentrasi $2 \mathrm{mg} / \mathrm{L}$ yaitu rerata 4,36 tunas (8 MST). Jumlah tunas paling sedikit yaitu rerata 2,01 tunas terdapat pada konsentrasi $0 \mathrm{mg} / \mathrm{L}$. Perlakuan IAA secara statistik tidak memberikan pengaruh terhadap jumlah tunas. Konsentrasi IAA $0 \mathrm{mg} / \mathrm{L}$ memiliki nilai rataan tertinggi yaitu 3,84 tunas (8 MST). Pertumbuhan tunas tanaman anggrek Cymbidium disajikan pada Gambar 1.
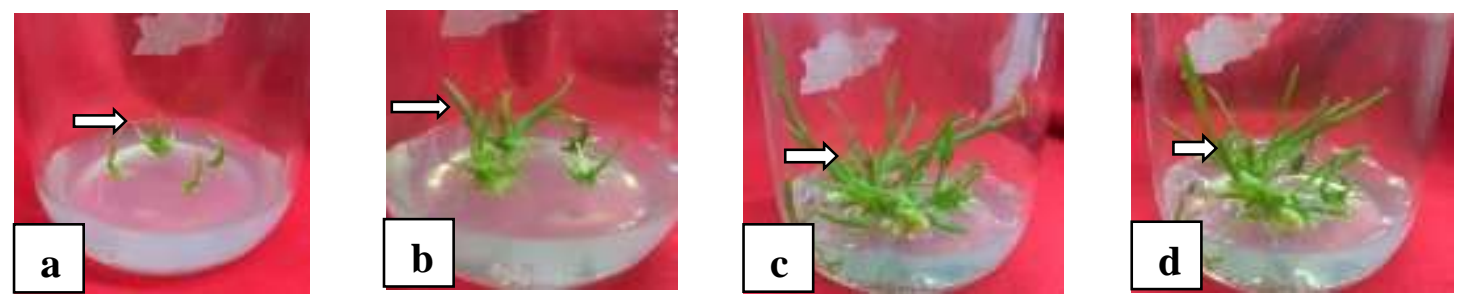

Gambar 1. Tunas anggrek Cymbidium perlakuan B1I0 (BAP $1 \mathrm{mg} / \mathrm{L}+\mathrm{IAA} 0 \mathrm{mg} / \mathrm{L}$ ). (a) $2 \mathrm{MST}$; (b) 4 MST; (c) 6 MST; (d) 8 MST

Gambar 1 memperlihatkan bahwa pertumbuhan dan perkembangan tunas pada perlakuan B1I0 (BAP $1 \mathrm{mg} / \mathrm{L}+\mathrm{IAA} 0 \mathrm{mg} / \mathrm{L})$. Gambar 1a menunjukkan pertumbuhan tunas pada umur 2 MST masih sedikit dengan ukuran tunas yang kecil. Gambar 2b menunjukkan pertumbuhan tunas 
sudah mulai meningkat dan ukuran tunasnya juga sudah mulai membesar. Gambar 1c dan 1d memperlihatkan jumlah tunas semakin banyak seiring dengan bertambahnya tinggi tunas yang tumbuh pada eksplan.

Jumlah tunas dapat diindikasi sebagai keberhasilan multiplikasi dalam kultur jaringan. Perlakuan BAP tunggal konsentrasi $2 \mathrm{mg} / \mathrm{L}$ menghasilkan jumlah tunas terbanyak dibandingkan dengan konsentrasi $0 \mathrm{mg} / \mathrm{L}$ dan $1 \mathrm{mg} / \mathrm{L}$ (Tabel 4). Penambahan BAP $1 \mathrm{mg} / \mathrm{L}$ dan $2 \mathrm{mg} / \mathrm{L}$ dapat mengahasilkan jumlah tunas yang lebih baik dibandingkan tanpa penambahan BAP. Pemberian BAP dengan konsentrasi hingga 2 $\mathrm{mg} / \mathrm{L}$ cenderung meningkatkan persentase pembentukan tunas, namun persentase pembentukan tunas akan menurun seiring dengan peningkatan konsentrasi BAP yang diberikan. Hal ini sesuai dengan pernyataan Mahadi (2016) bahwa penambahan BAP hingga konsentrasi 2 $\mathrm{mg} / \mathrm{L}$ dapat meningkatkan jumlah tunas pada tanaman anggrek Larat.

Pemberian IAA tidak berpengaruh terhadap jumlah tunas tanaman anggrek Cymbidium. Hal ini terjadi karena kandungan IAA endogen yang terdapat pada eksplan kemungkinan sudah mencukupi untuk pertumbuhantunas. Hasil penelitian Sudomo (2018) menunjukkan bahwa ZPT auksin yang diberikan di awal penanaman akan menginduksi tumbuhnya sel ujung mata tunas, pertumbuhan akar lateral dan akar serabut serta merangsang pembentukan tunas dan daun dengan cepat. Pernyataan tersebut tidak sejalan dengan hasil penelitian ini, diduga karena penambahan IAA eksogen akan menyebabkan konsentrasi IAA menjadi tinggi sehingga pertumbuhan jumlah

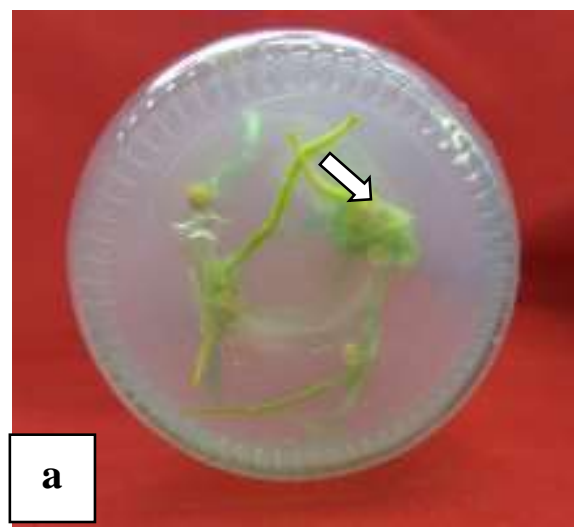

tunas menjadi terhambat. Penelitian Wahidah \& Hasrul (2017) menyatakan bahwa perlakuan dengan pemberian IAA konsentrasi tinggi mengakibatkan tanaman mensintesis ZPT lain seperti asam absisat (ABA) atau etilen yang dapat menghambat pemanjangan sel batang, menghambat pertumbuhan dan perkembangan daun dan batang.

Hasil pengamatan menunjukkan terdapat interaksi antara perlakuan BAP dan IAA, kombinasi BAP $1 \mathrm{mg} / \mathrm{L}$ dan IAA $0 \mathrm{mg} / \mathrm{L}$ menghasilkan jumlah tunas terbanyak. Hal ini sesuai dengan pernyataan Sadat et al. (2018) bahwa penggunaan konsentrasi auksin yang rendah dengan sitokinin yang tinggi dapat menghasilkan pembentukan tunas yang baik.

\section{Jumlah Akar}

Hasil analisis ragam menunjukkan tidak terdapat interaksi antara perlakuan BAP dan IAA terhadap jumlah akar tanaman anggrek Cymbidium. Perlakuan BAP tunggal berpengaruh terhadap jumlah akar pada 2 MST. Perlakuan IAA tidak berpengaruh terhadap jumlah akar tanaman anggrek Cymbidium. Data uji lanjut pada peubah jumlah akar akibat perlakuan konsentrasi BAP dan IAA disajikan pada Tabel 4.

Berdasarkan Tabel 4 dapat diketahui bahwa perlakuan BAP secara tunggal memberikan pengaruh terhadap jumlah akar pada umur 2 MST. Konsentrasi BAP $2 \mathrm{mg} / \mathrm{L}$ menghasilkan jumlah akar terbanyak. Perlakuan IAA tidak berpengaruh terhadap jumlah akar. Konsentrasi IAA $0 \mathrm{mg} / \mathrm{L}$ memberikan nilai rataan tertinggi yaitu rerata 1,47 (8 MST). Akar tanaman anggrek Cymbidium disajikan pada Gambar 2.

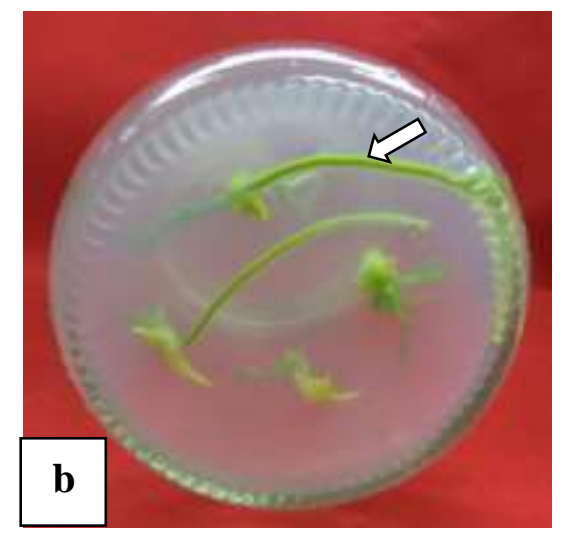

Gambar 2. Akar anggrek Cymbidium.(a)Perlakuan B1I2 (BAP 1 mg/L + IAA 1 mg/L);(b)Perlakuan B2I0 (BAP $2 \mathrm{mg} / \mathrm{L}+\mathrm{IAA} 0 \mathrm{mg} / \mathrm{L}$ )

Gambar 2 merupakan gambar akar anggrek Cymbidium pada umur 8 MST. Gambar 2a menunjukkan pertumbuhan akar pada perlakuan B1I2 (BAP $1 \mathrm{mg} / \mathrm{L}$ + IAA $1 \mathrm{mg} / \mathrm{L}$ ) memiliki jumlah yang sedikit dengan ukuran akar yang kecil. Gambar 2b memperlihatkan bahwa 
perlakuan B2I0 (BAP $2 \mathrm{mg} / \mathrm{L}$ + IAA $0 \mathrm{mg} / \mathrm{L}$ ) memiliki jumlah akar yang lebih banyak dan ukuran akar yang lebih besar.

Jumlah akar tanaman dapat mengindikasi seberapa luas jangkauan tanaman menyerap nutrisi, semakin banyak jumlah akar maka semakin banyak nutrisi yang diserap. Pemberian BAP pada subkultur anggrek Cymbidum menghasilkan jumlah akar yang tidak berbeda pada semua konsentrasi (Tabel 4). Hal ini terjadi karena konsentrasi sitokinin yang tinggi dapat menghambat pertumbuhan akar tanaman (Karjadi, 2007).

Pemberian IAA tidak berpengaruh terhadap jumlah akar tanaman anggrek Cymbidium. Penggunaan IAA dengan konsentrasi $0,5 \mathrm{mg} / \mathrm{L}$ dan $1 \mathrm{mg} / \mathrm{L}$ mungkin terlalu tinggi sehingga jumlah akar yang dihasilkan rendah. Pembentukan jumlah akar pada tanaman anggrek Cymbidium kemungkinansudah terpenuhi dengan memanfaatkan hormon IAA endogen yang terkandung di dalam eksplan serta unsur hara yang terdapat di dalam media dasar tanpa harus ditambahkan IAA eksogen. Menurut Hoesen et al. (2008), terbentuknya organ tanaman pada kultur in vitro akan dipengaruhi oleh kandungan nitrogen yang terdapat pada media dasar (Liwanza et al., 2019). Pembentukan dan perkembangan organ tanaman juga dipengaruhi oleh adanya nitrogen yang terkandung dalam media (Jailani et al., 2019).

\section{Persentase Kontaminasi}

Hasil analisis ragam menunjukkan tidak terdapat pengaruh antara pemberian BAP dan IAA terhadap peubah persentase kontaminasi. Datauji lanjut pada peubah persentase kontaminasi akibat perlakuan konsentrasi BAP dan IAA disajikan pada Tabel 5.

Berdasarkan Tabel 6 perlakuan BAP dan IAA tidak menunjukkan pengaruh terhadap peubah persentase kontaminasi. Konsentrasi BAP $2 \mathrm{mg} / \mathrm{L}$ dan IAA $0 \mathrm{mg} / \mathrm{L}$ memiliki nilai rataan tertinggi. Kontaminasi yang terjadi pada botol kultur disajikan pada Gambar 3.

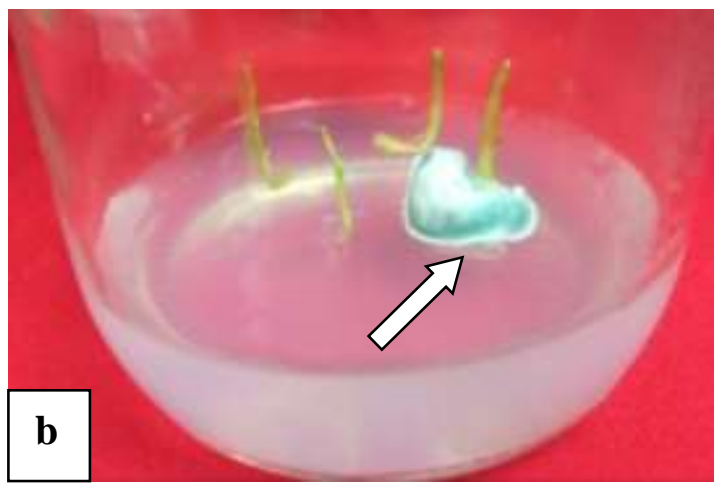

Gambar 3. Kontaminasi pada eksplan. (a) Perlakuan B1I1 (BAP1mg/L + IAA 0,5 mg/L);(b)Perlakuan B2I0 (BAP $2 \mathrm{mg} / \mathrm{L}+\mathrm{IAA} 0 \mathrm{mg} / \mathrm{L})$

Gambar 3a menunjukkan bahwa perlakuan B1I1 (BAP1mg/L + IAA 0,5 mg/L)mengalami kontaminasi pada minggu pertama setelah penanaman. Gambar 3b menunjukkan bahwa perlakuan B2I0 (BAP $2 \mathrm{mg} / \mathrm{L}$ + IAA $0 \mathrm{mg} / \mathrm{L}$ ) mengalami kontaminasi pada minggu kedua setelah penanaman.

Kontaminasi yang terjadi disebabkan oleh jamur yang mengakibatkan pertumbuhan eksplan menjadi terganggu. Kontaminasi yang disebabkan oleh jamur ditandai dengan munculnya hifa (benang-benang putih) yang terdapat pada pangkal eksplan. Hal ini sesuai dengan pernyataan Shofiyani (2015) bahwa kontaminasi yang disebabkan oleh jamur menunjukkan ciri-ciri terbentuknya lapisan hifa berwarna putih dan putih kelabu hitam di permukaan media yang terkontaminasi. Menurut
Astuti (2002) kegiatan perbanyakan tanaman secara kultur jaringan akan menyebabkan terjadinya kontaminasi yang disebabkan oleh 3 sumber kontaminan yakni eksplan yang digunakan, faktor media dan proses pelaksanaan. Kontaminasi yang bersumber dari proses pelaksanaan terjadi karena cara pembuatan media, serta penggunaan alat-alat yang kurang aseptik sehingga memberikan peluang bagi jamur untuk tumbuh dan berkembang di dalam media. Sedangkan kontaminasi yang bersumber dari eksplan yang digunakan terjadi karena penggunaan eksplan yang kurang steril sehingga jamur yang ada pada eksplan masuk kedalam botol kultur dan menyebabkan terjadinya kontaminasi. 


\section{Jumlah Daun}

Hasil analisis ragam menunjukkan tidak terdapat interaksi antara perlakuan BAP dan IAA terhadap peubah jumlah daun tanaman anggrek Cymbidium. Data uji lanjut pengaruh perlakuan BAP dan IAA secara tunggal terhadap jumlah daun disajikan pada Tabel 6.

Berdasarkan Tabel 6 dapat diketahui bahwa perlakuan BAP memberikan pengaruh terhadap jumlah daun tanaman anggrek

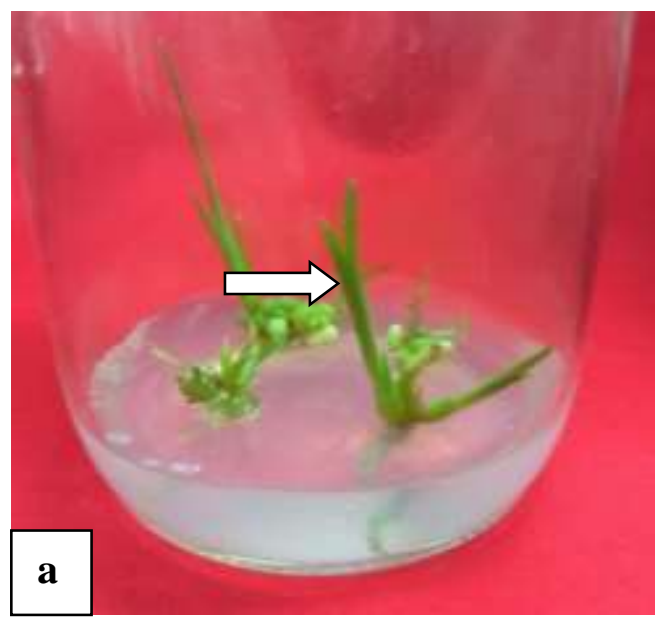

Cymbidium. Jumlah daun terbanyak terdapat pada konsentrasi BAP $2 \mathrm{mg} / \mathrm{L}$ yaitu rerata 1,56 daun $(8$ MST). Jumlah daun terendah terdapat pada konsentrasi BAP $0 \mathrm{mg} / \mathrm{L}$ yaitu rerata 0,76 daun $(8$ MST). Perlakuan IAA tidak memberikan pengaruh terhadap jumlah daun tanaman anggrek Cymbidum. Perlakuan IAA dengan konsentrasi 0 $\mathrm{mg} / \mathrm{L}$ memiliki nilai rataan tertinggi yaitu rerata 1,30 daun (8 MST). Daun tanaman anggrek Cymbidum disajikan pada Gambar 4.

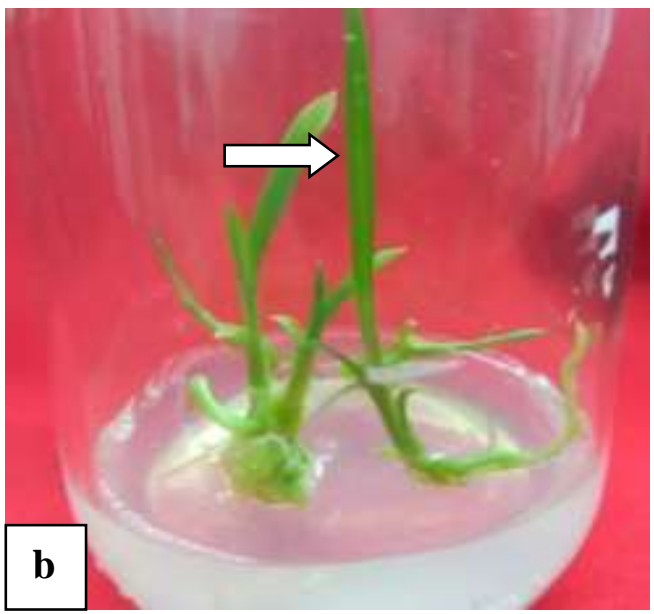

Gambar 4. Daun anggrek Cymbidium perlakuan B2I0 (BAP 2 mg/L + IAA 0 mg/L). (a) 6 MST; (b) 8 MST

Gambar 4 menunjukkan bahwa perlakuan B2I0 merupakan perlakuan yang menghasilkan jumlah daun terbanyak. Gambar 4a menunjukkan pertumbuhan daun sudah mulai terlihat pada umur 6 MST dengan jumlah daun yang sedikit. Gambar 4b menunjukkan jumlah daun sudah mulai bertambah yaitu berkisar antara 2 sampai 3 helai daun yang terdapat dalam satu eksplan.

Perlakuan BAP berpengaruh terhadap peubah jumlah daun. Konsentrasi BAP $2 \mathrm{mg} / \mathrm{L}$ menghasilkan jumlah daun terbanyak, karena BAP dapat memacu peningkatan produksi klorofil yang berpengaruh pada proses fotosintesis. Rosniawaty et al.(2017) menyatakan bahwa BAP merupakan zat pengatur tumbuh yang mengandung senyawa nitrogen yang berperan untuk mengoptimalkan proses sintesis asam-asam amino dan protein. Asam-asam amino dan protein tersebut yang kemudian dimanfaatkan untuk pertumbuhan daun. Penelitian Sasmita (2018) juga menyatakan bahwa perlakuan BAP 1 ppm memiliki nilai tertinggi terhadap jumlah daun angrek Cymbidium (Cymbidium finlaysonianum Lindl.) yaitu 5,17 helai. Penelitian Fithriyandini (2015) juga menyebutkan bahwa penggunaan BAP konsentrasi 2,5 mg/L menghasilkan jumlah daun terbaik pada tanaman anggrek bulan (Phalaenopsis amabilis). Pernyataan tersebut hampir sama dengan hasil penelitian yang telah dilakukan bahwa pemberian BAP mempengaruhi jumlah daun yang dihasilkan oleh planlet anggrek cymbidium.

Perlakuan IAA tidak berpengaruh terhadap peubah jumlah daun. Hal ini diduga karena kandungan hormon auksin endogen sudah mencukupi untuk memacu pembelahan sel dan diferensiasi sel menjadi tunas-tunas baru. Berdasarkan Tabel 6 dapat dilihat bahwa perlakuan I0 dan I1 memiliki jumlah daun yang relatif hampir sama yaitu rerata 1,30 helai dan 1,29 helai. Hal ini disebabkan karena peningkatan konsentrasi auksin dapat menghambat pertumbuhan daun, tetapi berfungsi dalam pembesaran sel.

Faktor interaksi pemberian BAP dan IAA tidak berpengaruh terhadap jumlah daun. Sesuai dengan penelitian Ilham (2019) menyatakan bahwa interaksi pemberian BAP dan IAA tidak berpengaruh terhadap jumlah daun talas satoimo (Colocasia esculenta L.). Hal ini terjadi karena pemberian zat pengatur tumbuh yang kurang optimal menyebabkan respon tanaman terhadap zat pengatur tumbuh tidak sesuai.

\section{Tinggi Tunas}

Hasil analisis ragam menunjukkan bahwa perlakuan BAP dan IAA serta interaksinya tidak berpengaruhterhadap tinggi tunas tanaman 
anggrek Cymbidium. Data uji lanjut pada peubah tinggi tunas akibat perlakuan konsentrasi BAP dan IAA secara tunggal disajikan pada Tabel 7.

Berdasarkan Tabel 7 perlakuan BAP dan IAA tidak berpengaruh terhadap tinggi tunas tanaman anggrek Cymbidium. Tinggi tunas

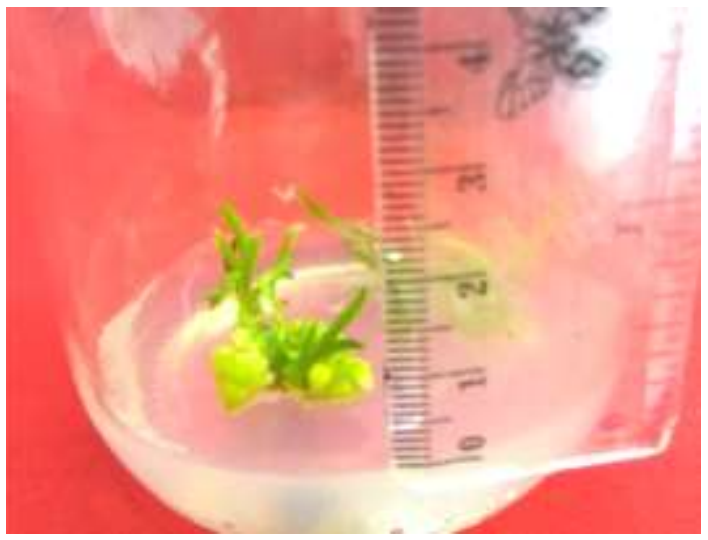

terbaik secara rataan terdapat pada konsentrasi BAP $1 \mathrm{mg} / \mathrm{L}$ yaitu $2,87 \mathrm{~cm}$ dan pada konsentrasi IAA $1 \mathrm{mg} / \mathrm{L}$ yaitu $2,68 \mathrm{~cm}$. Tinggi tunas tanaman anggrek Cymbidium disajikan pada Gambar 5.

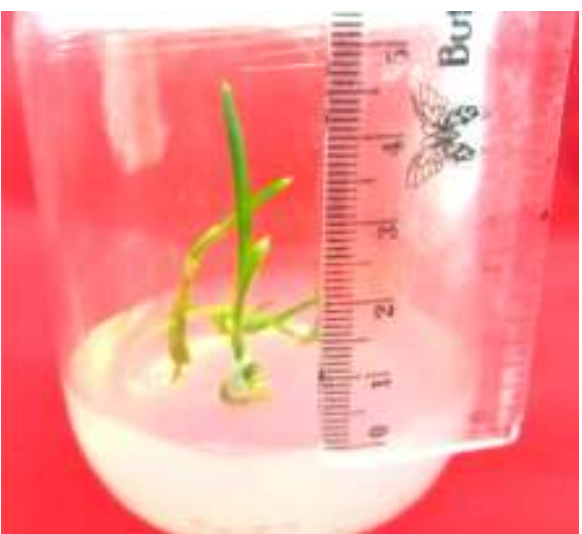

Gambar 5. Tinggi tunas anggrek Cymbidium. (a)Perlakuan B1I0 (BAP 1 mg/L + IAA 0 mg/L);(b) Perlakuan B1I1 (BAP1mg/L + IAA 0,5 mg/L)

Gambar 5 menunjukkan bahwa perlakuan B1I0 (BAP $1 \mathrm{mg} / \mathrm{L}+$ IAA $0 \mathrm{mg} / \mathrm{L})$ menghasilkan tinggi tunas yang tinggi dibandingkan dengan perlakuan B1I1 $(\mathrm{BAP} 1 \mathrm{mg} / \mathrm{L}+$ IAA $0,5 \mathrm{mg} / \mathrm{L})$ yang menghasilkan tinggi tunas yang lebih rendah. Tinggi tunas diukur dari pangkal tunas sampai titik tertinggi dari pertumbuhan tunas.

Berdasarkan hasil penelitian pemberian BAP tidak berpengaruh terhadap tinggi tunas. Hal ini sesuai dengan penelitian Prayoga (2009) bahwa pemberian BAP tidak berpengaruh terhadap panjang tunas mikro pisang raja. Penggunaan BAP dengan konsentrasi yang tinggi pada media kultur menghasilkan pertambahan jumlah tunas yang terbentuk, namun ukuran panjangnya berkurang. Hal tersebut terjadi karena BAP lebih berperan dalam memacu pembelahan sel dan diferensiasi sel menuju pembentukan tunas, tetapi tidak berpengaruh terhadap perpanjangan tunas.

Pemberian IAA tidak berpengaruh terhadap tinggi tunas tanaman anggrek Cymbidium. Hal ini disebabkan oleh penggunaan konsentrasi IAA yang kurang optimal. Karjadi (2007) menyatakan bahwa penggunaan auksin dalam konsentrasi yang rendah akan menstimulasi pembesaran dan perpanjangan sel batang setelah terjadinya pembelahan sel yang distimulir oleh sitokinin. Penggunaan konsentrasi auksin yang terlalu tinggi akan menyebabkan terhambatnya pemanjangan sel. Semakin tinggi konsentrasi auksin, konsentrasi etilen yang dihasilkan akan semakin tinggi, hal ini akan menyebabkan terhambatnya aktivitas auksin dalam perpanjangan sel, tetapi akan meningkatkan pelebaran sel.

Hasil penelitian menunjukkan bahwa tidak terdapat interaksi antara pemberian BAP dan IAA terhadap tinggi tunas anggrek Cymbidium. Penelitian Mufa'adi (2004) menyatakan bahwa interaksi pemberian BAP dan IAA memberikan pengaruh pada peubah tinggi tunas. Pernyataan tersebut tidak sejalan dengan hasil penelitian yang telah dilakukan terhadap tinggi tunas. Hal ini diduga karena penggunaan konsentrasi BAP dan IAA yang digunakan belum memenuhi komposisi ZPT yang dibutuhkan tanaman.

\section{KESIMPULAN}

1. Perlakuan BAP berpengaruh terhadap pertumbuhan sub kultur anggrek Cymbidium pada peubah waktu tumbuh tunas, jumlah tunas (2, 4, 6, 8 MST), jumlah akar (2 MST), jumlah daun (6 dan 8 MST), dan persentase tumbuh tunas ( 2 dan 4 MST). Perlakuan terbaik terdapat pada perlakuan BAP $1 \mathrm{mg} / \mathrm{L}$.

2. Perlakuan IAA berpengaruh terhadap pertumbuhan sub kultur anggrek Cymbidium pada peubah jumlah tunas (4 MST). Perlakuan terbaik terdapat pada perlakuan IAA $0 \mathrm{mg} / \mathrm{L}$.

3. Terdapat interaksi antara kombinasi perlakuan BAP dan IAA terhadap pertumbuhan sub kultur anggrek Cymbidium pada peubah jumlah tunas dan persentase tumbuh tunas pada umur 4 MST. Interaksi perlakuan terbaik terdapat pada perlakuan BAP $1 \mathrm{mg} / \mathrm{L}$ + IAA $0 \mathrm{mg} / \mathrm{L}$. 


\section{DAFTAR PUSTAKA}

Alitalia, Y. 2008. Pengaruh Pemberian BAP dan NAA Terhadap Pertumbuhan dan Perkembangan Tunas Mikro Kantong Semar (Nephenthes mirabilis) Secara In vitro. (Skripsi) Fakultas Pertanian. Institut Pertanian Bogor. Bogor.

Amalia, R., Lovadi, I., Linda, R. 2015. Kekayaan jenis anggrek di hutan alam Desa Beginjan Kecamatan Tayan Hilir Kabupaten Sanggau. Jurnal Protobiont 4 (1), 170-177.

Astuti. 2002. Pengaruh konsentrasi BA dalam media MS (Murashige and Skoog) terhadap pertumbuhan meristem beberapa varietas nanas (Ananas comusus L.). Jurnal Buana Sains 2(2), 212-217.

Elfiani., Jakoni. 2015. Sterilisasi eksplan dan sub kultur anggrek, sirih merah dan krisan pada perbanyakan tanaman secara In vitro. Jurnal Dinamika Pertanian (30)2, 117-124.

Fithriyandhini, A., Maghfoer, M. D., Wardiyati, T. 2015. Pengaruh media dasar dan 6Benzylaminopurine (BAP) terhadap pertumbuhan dan perkembangan nodus tangkai bunga anggrek bulan (Phalaenopsis amabilis) dalam perbanyakan secara in vitro. Jurnal produksi Tanaman 3 (1), 43-49

George, E. F. and P. D. Sherrington. 1984. Plant Propagation by Tissue Culture. England. Exegetics Limited.

Hoesen, D. S. H., Witjaksono., Sukamto, L. A. 2008. Induksi kalus dan organogenesis kultur in vitro Dendrobium Lineale Rolfe. Jurnal Pusat Penelitian Biologi 9 (3), 333-341.

Ilham, Muhammad, Sugiyono, L., P. 2019. Pengaruh interaksi BAP dan IAA terhadap multiplikasi tunas Talas Satoimo (Colocasia esculenta L.) Schoot var. Antiquorum secara in vitro. Jurnal Ilmiah Biologi Unsoed 1 (1), 4855.

Inkirawang, A. E. B., Mandang, J., Runtunuwu, S. 2016. Substitusi media Murashige Skoog (MS) dengan air kelapa dan pupuk daun majemuk pada pertumbuhan anggrek Dendrobium secara in vitro. Jurnal Biologis 6(1), 1519.

Jailani, S. Ratnawaty, Nasruddin, Faisal, Ismadi. 2019. Respon Tanaman Terung (Solanum melongena L.) Pada Berbagai Media Tanaman dan Dosis Pupuk NPK. Agrium. 16(2): 151-159

Jihadiyah, Khanifatul. 2018. Efektivitas
Beberapa Auksin (IBA, IAA, dan NAA) Terhadap Induksi Akar Tanaman Tin (Ficus carica L.) Melalui Teknik Stek Mikro. (Skripsi) Jurusan Biologi, Fakultas Sains dan Teknologi, Universitas Islam Negeri Maulana Malik Ibrahim.

Karjadi,A. K., Buchory, A. 2007. Pengaruh NAA dan BAP terhadap pertumbuhan jaringan meristem bawang putih pada media B5. J. Hort. 17 (3), 217-223.

Liwanza, N. Muksalmina, Ismadi, Handayani, R. S. 2019. Keberhasilan Sambung Pucuk Durian (Durio zibethinus) Lokal Aceh Akibat Perlakuan Cara dan Lama Penyimpanan Batang Atas. Agrium. 16(2): 166-170.

Mahadi, Imam. 2016. Multifikasi tunas Anggrek Larat (Dendrobiumphalaenopsis Fitzg) dengan pemberian hormon IAA dan BAP terhadap pertumbuhan secara in vitro. EKSAKTA, 2, 1-6.

Maninggolang, A., Mandang, J. Sh. P., T. W. 2018. Pengaruh BAP (Benzyl amino purine) dan air kelapa terhadap pertumbuhan tunas pucuk dan kandungan sulforafan brokoli (Brassica oleracea L. Var. Italica Plenck) secara in vitro. Jurnal AgriSosioEkonomi 14 (1), 585-596.

Mashud, Nurhaini. 2013. Efek zat pengatur tumbuh BAP terhadap pertumbuhan plantlet genjah kopyor dari kecambah yang dibelah. Jurnal B. Palma 14 (2), 82-87.

Mufa'adi, A., S. A. A., D. D. 2003. Pengaruh kombinasi zat pengatur tumbuh BAP dan IAA terhadap pertumbuhan dan perkembangan tanaman Daun Dewa (Gynura procumbens (Back.)) dalam kultur in vitro. Bul. Agron 32 (3), 4452.

Mukarlina, Arti, L. T. 2017. Multiplikasi Anggrek Bulan (Dendrobium sp.) dengan penambahan ekstrak taoge dan Benzyl Amino Purin (BAP) secara in vitro. Jurnal Protobiont 6 (3), 278-282.

Prayoga, L. 2009. Pengaruh media dan konsentrasi BAP terhadap pertumbuhan tunas mikro Pisang Raja secara in vitro. Agritech 11 (2), 96-106.

Purita, S. Y., Ardiarini, N. R., Basuki, N. 2017. Pengaruh zat pengatur tumbuh jenis BAP terhadap pertumbuhan planlet subkultur jaringan tanaman nanas (Ananas comosus L. Merr). Jurnal 
produksi Tanaman 5 (7), 1207-1212.

Raharjo, S. H. T., Hehanussa, M., L., Tuhuteru, S. 2012. Pertumbuhan dan perkembangan anggrek Dendrobium anosmum pada media kultur in vitro dengan beberapa konsentrasi air kelapa. Jurnal Agrologia 1 (1), 1-12.

Rosniawaty, S., Seafas, S. A. S., Maxiselly, Y. 2017. Pengaruh konsentrasi zat pengatur tumbuh alami dan sintetik terhadap pertumbuhan tanaman teh (Camelia sinensis (L.)O. Kuntze) klon GMB 7 setelah centering. Jurnal Kultivasi 16 (2), 368-372.

Sadat, M. S., Siregar, L. A. M., Setiado, H. 2018. Pengaruh IAA dan BAP terhadap induksi tunas mikro dari eksplan bonggol pisang kepok (Musa paradisiaca L.). Jurnal Agroekoteknologi 6 (1), 107-112.

Sasmita, L. 2018. Pengaruh Penambahan Sitokinin dan Auksin Pada Media MS Terhadap Pertumbuhan Sub Kultur AnggrekCymbidiumSecara In Vitro. (Skripsi) Universitas Malikussaleh. Aceh Utara.

Sudomo, A., Turjaman, M. 2018. Pengaruh zat pengatur tumbuh terhadap pertumbuhan setek pucuk jamblang (Syzygium cumini (L.) Skeels). Jurnal
Perbenihan Tanaman Hutan 6 (2), 93105.

Suhita, A., W., S. 2008. Pengaruh Konsentrasi BAP dan Macam Media Terhadap Pertumbuhan Awal Anthurium hookeri. (Skripsi) Jurusan Agronomi, Fakultas Pertanian, Universitas Sebelas Maret.

Sulasiah, A., Tumilisar, C., Lestari, T. 2015. Pengaruh pemberian jenis dan konsentrasi auksin terhadap induksi perakaran pada tunas Dendrobium sp. secara in vitro. Bioma, 56-66.

Wahidah, B., F., Hasrul. 2017. Pengaruh pemberian zat pengatur tumbuh Indole Acetic Acid (IAA) terhadap pertumbuhan tanaman pisang sayang (Musa paradisiaca L. Var. Sayang) secara in vitro. Jurnal Teknosains 11 (1), 27-41.

Widiastoety, D., Nurmalinda. 2010. Potensi Anggrek Dendrobium dalam meningkatkan variasi dan kualitas anggrek bunga potong. Jurnal Litbang Pertanian 29 (3), 101-106.

Yuniati, F., Sri, H., Erma, P. 2018. Pengaruh hormon dan ukuran eksplan terhadap pertumbuhan mata tunas tanaman pisang (Musa paradisiaca var. Raja Bulu) secara in vitro. Buletin Anatomi dan Fisiologi 3(1) 20-28. 